\title{
IMPLEMENTASI MODEL PEMBELAJARAN DALAM JARINGAN (DARING) PADA KEGIATAN PEMBELAJARAN TEMATIK DI MASA PANDEMI COVID-19 KELAS IV SDN GUBENG I/204 SURABAYA
}

\section{Sri Juniati}

Dinas Pendidikan Kota Surabaya Jawa Timur, Indonesia

Email: fiandyan45@gmail.com

\begin{abstract}
Abstrak
Pembelajaran daring pertama kali diperkenalkan oleh Universitas Illionis di Urbana Champagn dengan menggunakan sistem instruksi berbasis computer. Dengan adanya pembelajaran daring siswa dapat melakukan proses belajar mengajar secara efektif dan efisien pada masa pandemi covid-19. Penelitian ini bertujuan untuk mendeskripsikan mengenai implementasi model pembelajaran dalam jaringan (daring) pada kegiatan pembelajaran tematik di masa pandemi covid-19 kelas IV SDN Gubeng 1 / 204 Surabaya. Jenis penelitian yang dilakukan adalah peneliti deskriptif kualitatif yang berusaha mendeskripsikan suatu gejala, peristiwa, kejadian yang terjadi pada saat sekarang. Sumber data yang digunakan adalah guru kelas IV, siswa kelas IV dan orang tua dari kelas IV. Teknik pengumpulan data dengan cara observasi, wawancara, dan dokumentasi. Dari hasil penelitian dapat disimpilkan bahwa: implementasi model pembelajaran dalam jaringan (daring) pada kegiatan pembelajaran tematik di masa pandemi covid-19 kelas IV SDN Gubeng 1 / 204 Surabaya telah diwujudkan dengan 3 tahap, yaitu tahap perencanaan dengan pembuatan rencana pelaksanaan pembelajaran (RPP), silabus, media pendidikan serta materi yang akan disampaikan. Tahap kedua, yaitu tahap pelaksanaan pembelajaran atau inti pembelajaran daring ada yang secara individu dan ada yang kelompok. Pada saat berkelompok guru membagi maksimal lima siswa masing-masing kelompok yang rumahnya berdekatan kemudian siswa membaca materi, mengamati, dan berdiskusi. Setelah berdiskusi siswa lalu mengerjakan soal evaluasi. Pada saat pembelajaran individu siswa biasanya membaca materi, mengamati, berdiskusi sampai mengerjakan tuas mandiri di buku tugas masing-masing. Tahap yang ketiga yaitu evaluasi pembelajaran yang dilakukan guru mengutamakan penilaian kognitif (pengetahuan) siswa melalui hasil mengerjakan latihan soal di LKS, tugas maupun PR.
\end{abstract}

Kata Kunci: Model pembelajaran dalam jaringan (daring); pembelajaran tematik

\section{Abstract}

Online learning was first introduced by the University of Illinois in Urbana Champagn using a computer-based instruction system. With online learning students can do the teaching and learning process effectively and efficiently during the covid-19 pandemic. This research aims to describe the implementation of online learning models in thematic learning activities during

$\begin{array}{ll}\text { How to cite: } & \text { Juniati, S., (2021) Implementasi Model Pembelajaran Dalam Jaringan (Daring) Pada Kegiatan } \\ & \text { Pembelajaran Tematik Di Masa Pandemi Covid-19 Kelas Iv Sdn Gubeng I/204 Surabaya, Syntax } \\ & \text { Idea, 3(12), https://doi.org/10.36418/syntax-ideav3i11.1542 } \\ \text { E-ISSN: } & \text { 2684-883X } \\ \text { Published by: } & \text { Ridwan Institute }\end{array}$


the covid-19 pandemic class IV SDN Gubeng 1 / 204 Surabaya. The type of research conducted is a qualitative descriptive researcher who seeks to describe a symptom, event, event that occurs in the present moment. The data sources used are grade IV teachers, grade IV students and parents from class IV. Data collection techniques by means of observation, interview, and documentation. From the results of the research it can be noted that: the implementation of the online learning model in thematic learning activities in the covid-19 pandemic class IV SDN Gubeng $1 / 204$ Surabaya has been realized with 3 stages, namely the planning stage with the creation of an implementation plan. learning (RPP), syllabus, educational media and materials to be delivered. The second stage, namely the stage of learning implementation or the core of online learning there are individual and some are group. When the group of teachers divides a maximum of five students each group whose houses are adjacent then students read the material, observe, and discuss. After discussing the students and then working on the evaluation. At the time of individual learning students usually read the material, observe, discuss until working on the lever independently in their respective task books. The third stage is the evaluation of learning conducted by teachers prioritizes cognitive assessment (knowledge) of students through the results of doing problem exercises in LKS, assignments and homework.

Keywords: Online learning model; thematic learning;

Received: 2021-11-22; Accepted: 2021-12-05; Published: 2021-12-20

\section{Pendahuluan}

Salah satu ahli yaitu Dahama \& Bhatnagar mengatakan bahwa definisipendidikan menurutnya adalah suatu proses membawa perubahan yang diinginkan dalam perilaku manusia. Dapat juga didefinisikan sebagai proses perolehan pengetahuan dan kebiasaankebiasaan melalui pembelajaran atau studi (Ahmadi, 2016). Dalam (UU No.20 tahun 2013, 2013) pada Pasal 1 ayat 1, yang menjelaskan tentang pengertian pendidikan bahwa: Pendidikan adalah usaha sadar dan terencana untuk mewujudkan belajar dan proses pembelajaran agar peserta didik secara aktif mengembangkan potensi dirinya untuk memilih kekuatan spiritual keagamaan, pendidikan, kecerdasan, akhlak mulia, serta keterampilan yang di perlukan dirinya dan masyarakat, bangsa dan negara (Depdiknas, 2003).

Pendidikan selalu dapat dibedakan menjadi teori dan praktek, karena pendidikan suatu pengetahuan tentang makna dan bagaimana seyogyanya pendidikan di laksanakan, sedangkan praktek adalah tentang pelaksanaan pendidikan secara konkretnya (nyata) (Hasbullah, 2012). Dalam arti sederhana pendidikan sering diartikan sebagai usaha manusia untuk membina kepribadiannya sesuai dengan nilai-nilai di dalam masyarakat dan kebudayaan. Dalam berkembangnya, istilah pendidikan berarti bimbingan atau pertolongan yang diberikan dengan sengaja oleh orang dewasa agar menjadi dewasa. Selanjutnya pendidikan sering diartikan sebagai usaha yang dijalankan oleh seseorang atau sekelompok orang lain agar menjadi dewasa atau mecapai tingkat hidup atau 
penghidupan yang lebih tinggi dalam arti mental. Dan nyatanya pendidikan sekarang mengalami perkembangan meskipun secara essensial tidak jauh berbeda (Hasbullah, 2012).

Dunia pendidikan adalah sesuatu yang sangat penting bagi seorang manusia, karena pendidikan membuat manusia berkembang lebih baik kedepannya. Tidak ada hal yang tiak berkembang begitupun manusia, tidak ada manusia yang hanya berada pada titik yang sama tidak memiliki perkembangan yang maju dalam perkembangan zaman, dan semuanya bermula pada sebuah pendidikan. Suatu proses pendidikan tidak lepas dari sebuah pembelajaran. Pembelajaran merupakan suatu sistem atau proses membelajarkan subjek didik atau pembelajaran yang direncanakan atau didesain, dilaksanakan dan dievaluasi secara sistematis agar pembelajaran dapat mencapai tujuantujuan pembelajaran secara efektif dan efisien (Nawafil, 2018). Dengan demikian, jika pembelajaran dipandang sebagai suatu sistem, berarti pembelajaran terdiri atas sejumlah komponen yang terorganisasi antara tujuan pembelajaran, materi pembelajaran, strategi dan metode pembelajaran, media pembelajaran, perorganisasian kelas, evaluasi pembelajaran dan tindak lanjut pembelajaran. Sebaliknya, jika pembelajaran dipandang sebagai suatu proses maka pembelajaran merupakan rangkaian upaya atau kegiatan guru dalam rangka membuat peserta didik belajar. Pembelajaran merupakan suatu sistem maka dibutuhkan peran dari masing-masing komponen agar dapat mencapai tujuan yang telah ditetapkan (Erwin Widiosworo, 2015). Perubahan atau perkembangan pendidikan adalah hal yang memang seharusnya terjadi sejalan dengan perubahan budaya kehidupan manusia. Perubahan dalam arti perbaikan pendidikan pada semua tingkat perlu terus menerus dikakukan sebagai antisipasi kepentingan masa depan dengan tututan masyarakat modern. Hal ini tentu saja menyangkut berbagai bidang, tidak terkecuali bidang pendidikan. Komponen yang melekat pada pendidikan diantaranya adalah kurikulum (Sofan Amri, 2013). Sebuah pendidikan tentunya memiliki rancangan pembelajaran yang nantinya akan diberikan kepada peserta didik atau sering disebut kurikulum. Kurikulum adalah seperangkat rencana dan peraturan mengenai isi dan bahan pelajaran serta cara yang di gunakan sebagai pedoman penyelenggaraan kegiatan belajar mengajar. Hubungan antar kurikulum dengan pembelajaran saling terkait, pengembangan kurikulum hendaknya memerhatikan prinsip-prinsip kegiatan belajar, dan sebaiknya perencanaan kegiatan pengajaran harus memperhatikan gambaran menyeluruh yang tercakup dalam kurikulum. Kurikulum menempati posisi yang sangat menentukan dalam sebuah Pendidikan (Wahyuni, 2015). Ibarat tubuh, kurikulum merupakan jantungnya Pendidikan (Sofan Amri, 2013). Di Indonesia sudah diterapkan kurikulum 2013. Perkembangan dalam kurikulum 2013 ini terletak pada pengemasan yang memperjelas prosesnya melalui pembelajaran tematik. Pembelajaran tematik dimaknai sebagai pembelajaran yang dirancang berdasarkan tema-tema tertentu sehingga dapat memberikan pengalaman terhadap siswa. Dalam pembahasannya tema itu ditinjau dari berbagai mata pelajaran. Tematik adalah lambang dari seluruh bahasa pelajaran yang memfalitasi siswa untuk produktif menjawab pertanyaan yang dimunculkan sendiri dan 
memuaskan rasa ingin tahu dengan penghayatan secara alamiah tentang sekitar merek (Trianto, 2010).

Namun melihat kondisi negara Indonesia yang masih belum aman dari virus covid-19 pemerintah Indonesia pada tanggal 24 Maret 2020 melalui Menteri Pendidikan dan Kebudayaan Republik Indonesia mengeluarkan Surat Edaran Nomor 4 Tahun 2020 tentang pelaksanaan kebijakan pendidikan dalam masa darurat penyebaran covid-19, pemerintah mengeluarkan surat edaran tersebut agar proses belajar dapat dilaksanakan di rumah atau melalui pembelajaran daring guna untuk mencegah penyebaran wabah tersebut (Dewi, 2020). Karena dampak penyebaran virus covid-19 sangat mengganggu dunia pendidikan di Indonesia. Covid-19 adalah sebuah nama baru untuk pasien dengan infeksi virus novel corona-19 yang pertama kali dilaporkan dari kota Wuhan, China pada akhir 2019. Penyebaran virus terjadi secara cepat yang membuat ancaman pandemi baru. Penyebab dari virus ini diketahui pasti termasuk sejenis virus Ribose Nucleice Acid (RNA) yaitu virus corona jenias baru, Batacorona Virus dan salah satu virus corona penyebab Sevare Acute Respiratory Syndrome (SARS) dan Middle East Respiratory Syndrome (MERS) (CoV). Diagnosis ditegaskan dengan resiko perjalanan dari negara terjangkit dalam kurun waktu 14 hari disertai gejala infeksi saluran pernafasan atas atau bawah, disertai bukti laboraturium Real time polymerase chain reaction (RT-PCR) COVID-19 (Handayani, Hadi, Isbaniah, Burhan, \& Agustin, 2020). Dampak yang diberikan covid-19 pada kegiatan belajar mengajar cukup terasa. Hal tersebut terlihat dari pembelajaran yang semestinya dilakukan secara langsung sekarang hanya dapat dilakukan secara mandiri. Beberapa negara memutuskan terpaksa untuk menutup sekolah sebagai upaya pencegahan penyebaran covid-19, World Health Organization (WHO) merekomendasikan untuk menghentikan sementara kegiatankegiatan yang akan berpotensi menimbulkna kerumunan masa. Bahkan selama merebahnya virus covid-19 banyak cara yang dilakukan pemerintah Indonesia untuk pencegah penyebaran dengan social distancing, salah satunya dengan surat Edaran Kementrian Pendidikan dan Kebudayaan (Kemendikbud) Direktorat Pendidikan Tinggi No. 1 Tahun 2020 mengenai pencegahan penyebaran covid-19 di dunia Pendidikan. Dalam surat edaran tersebut Kemendikbud menganjurkan pembelajaran untuk seluruh sekolah di Indonesia menggunakan sistem daring sebagai upaya Study From Home (SFH) selama pandemi covid-19 (Handayani et al., 2020). Salah satu pembelajaran yang sangat cocok untuk diterapkan pada saat pandemi covid-19 adalah pembelajaran sistem dalam jaringan (daring) (Dini, 2021).

Daring merupakan sistem pembelajaran jarak jauh yang mengharuskan peserta didik untuk belajar dari rumahnya masing-masing. Proses belajar daring dilakukan untuk memberikan pengalaman belajar yang bermakna bagi siswa. Dengan pembelajaran daring merupakan pemanfaatan jaringan internet dalam proses belajar. Selain itu pembelajaran daring juga membuat siswa memiliki keleluasan belajar kapanpun dan dimanapun. Pembelajaran daring dilakukan dengan di sesuiakan kemampuan masing-masing sekolah. Pembelajaran daring dapat menggunakan 
teknologi digital seperti google classroom, rumah belajar, zoom, video, telepon, chat dan lainnya (Dewi, 2020).

SDN Gubeng 1 / 204 Surabaya merupakan salah satu lembaga pendidikan di tingkat dasar dengan Erin Megasusilowati selaku guru kelas IV. Dari hasil wawancara yang peneliti lakukan dengan dia pada tanggal 2 September 2020, dia mengatakan proses pembelajaran tematik kelas IV di SD Gubeng 1 / 204 Surabaya menerapkan sistem pembelajaran daring yang terhitung sejak bulan April-akhir semester. Pembelajaran daring dilakukan untuk membantu proses pembelajaran selama pandemi covid-19 agar tetap berjalan walaupun tidak secara tatap muka. Pada kelas IV, penerapan pembelajaran daring dilakukan setiap hari di rumah masing-masing siswa selama kurang lebih 2 jam dimulai dari pukul 08.00-10.00 WIB dengan melalui whatsapp group berupa voice note oleh guru kelas untuk menyampaikan materi pembelajaran dan pemberian tugas. Selain menggunakan voice note, pembelajaran daring juga dengan cara memberikan video-video tentang pembelajaran yang akan dibahas pada saat pembelajaran daring (Hasil Wawancara dengan Guru Kelas IV Ibu Erin Mega Susilowati SDN Gubeng 1 / 204 Surabaya, 2020). Berdasakan latar belakang masalah di atas, penulis tertarik untuk meneliti terkait dengan model pembelajaran daring pada kegiatan pembelajaran tematik di masa pandemi covid-19, khususnya kelas IV di Gubeng 1/204 Surabaya. Maka peneliti mengambil judul penelitian "Implementasi model pembelajaran daring pada kegiatan pembelajaran tematik dimasa.

\section{Metode Penelitian}

Objek dalam penelitian yang diteliti adalah Implementasi model pembelajaran daring pada pembelajaran tematik di masa pandemi covid-19 kelas IV SDN Gubeng 1 / 204 Surabaya.

Analisis data berarti menganalisa data dimana peneliti akan menyusun data-data yang diperoleh dari hasil observasi, dokumentasi, serta wawancara, catatan lapangan kedalam satu bagian yang utuh dan mengorganisasikannya kedalam beberapa kategori melakukan sintesa, menyusun ke dalam pola, memilih mana yang penting dan yang akan dipelajari, dan membuat kesimpulan sehingga hasil penelitian tersebut mudah dipahami oleh diri sendiri maupun orang lain yang akan mempelajarinya (Sugiyono, 2010). Teknik analisis data dalam penelitian ini adalah bersifat kualitatif dengan dilandasi oleh hasil atau keluaran dari setiap tindakan latihan yang diberikan kepada subjek penelitian (Emzir, 2008). Dalam penelitian kualitatif, analisis data merupakan upaya berlanjut, berulang, dan sistematis. Analisis dilakukan secara dua tahap, yaitu pada saat pengumpulan data dan setelah data terkumpul.

\section{Hasil dan Pembahasan}

Berdasarkan penyajian data di atas berdasarkan hasil observasi, wawancara, dan dokumentasi pada penerapan model pembelajaran dalam jaringan (daring) pada pembelajaran tematik maka peneliti menggunakan analisis deskriptif. Analisis ini meliputi analisis perencanaan, analisis pelaksanaan dan analisis evaluasi. Berikut 
analisis yang peneliti lakukan berdasarkan data yang telah disajikan pada pembahasan sebelumnya adalah sebagai berikut:

1. Analisis Perencanaan Pembelajaran

Perencanaan adalah proses yang harus dilakukan sebelum melakukan suatu kegiatan pada suatu periode tertentu dalam rangka mencapai tujuan.103 Dalam menganalisis data, peneliti menggunakan analisis deskriptif. Adapun proses analisis ini meliputi analisis perencanaan, analisis pelaksanaan, dan analisis penilaian atau evaluasi (Eka, 2021).

Pada tahap ini perencanaan pembelajaran yang dilakukan oleh guru kelas IV SDN Gubeng 1 / 204 Surabayasebelum melaksanakan pembelajaran dengan model pembelajaran dalam jaringan (daring) pada pembelajaran tematik guru melakukan tahapan perencanaan pembelajaran yang meliputi menyiapkan silabus, membuat RPP untuk setiap pertemuan. RPP yang digunakan adalah RPP satu lembar. RPP yang dibuat sebagai acuan dalam mengajar dan diharapkan sebagai memperlancar proses pembelajaran sehingga pembelajaran lebih terarah dan terjacapai tujuan dari pembelajaran. Guru juga menyiapkan materi pembelajaran yang akan disampaikan sebelum pembelajaran dimulai, kemudian guru juga menyiapkan media pembelajaran berupa leptop dan handphone untuk melakukan komunikasi pembelajaran dalam jaringan (daring). Serta menggunakan internet untuk mengakses video pada youtube untuk pembelajaran daring jika diperlukan. Dalam menyiapkan materi pembelajaran kelas IV, guru menyiapkan buku paket tematik kelas IV dan buku persada kelas IV (Wawancara bersama guru kelas IV SDN Gubeng 1 / 204 SurabayaErin Mega Susilowati, 2020).

\section{Analisis Pelaksanaan}

Dalam melaksanakan proses pembelajaran dalam jaringan (daring) pada pembelajaran tematik. Guru sudah memerisiapkan rencana pelaksanaan pembelajaran (RPP) yang terdiri dari kegiatan pendahuluan, kegiatan inti dan kegiatan akhir. Dalam melaksanakan pembelajaran guru sudah sesuai dengan langkah-langkah yang terdapat pada RPP.

Pada kegiatan pendahuluan guru memperisiapkan media pembelajaran dalam jaringan (daring) berupa leptop dan handphone serta materi pembelajaran yang terdapat pada buku. Memberi salam pada siswa serta guru menanyakan kesiapan siswa, kabar siswa dan kehadiran siswa dalam pembelajaran daring. Dalam kegiatan inti guru melakukan pembelajaran dengan menggunakan model pembelajaran dalam jaringan (daring). Daring merupakan salah satu model pembelajaran untuk menunjang proses pembelajaran di masa pandemi covid. Hampir semua mata pelajaran saat ini menggunakan model pembelajaran dalam jaringan (daring), hal ini dikarenakan untuk mengurangi proses penyebaran virus tersebut (Zidane, 2021).

Kegiatan inti pada tema 2, 3 dan tema 4 peneliti hanya mengobservasi 5 pembelajaran. Dalam pelaksanaan pembelajaran dalam jaringan (daring) guru membagi kegiatan menjadi beberapa tahap yaitu berdiskusi dan mengamati, hal ini 
dilakukan untuk menyesuaikan dalam melaksanakan pembelajaran sesuai tujuan pembelajaran yang terdapat pada RPP yang disampaikan dan waktu pembelajaran. Berikut adalah langkah-langkah kegiatan pembelajaran dalam jaringan (daring) pada pembelajaran tematik, yaitu:

a. Guru menyiapkan pembelajaran via dalam jaringan (daring) berupa

b. whatsapp dan youtube.

c. Guru membuat group bersama siswa.

d. Guru melakukan absensi untuk memasktikan kesiapan dan kehadiran siswa untuk melakukan pembelajaran daring.

e. Guru menyajikan dan menjelaskan materi pembelajaran melalui

f. whatsapp voice note atau youtube.

g. Guru mengirimkan materi atau bahan ajar.

h. Guru memberikan tugas harian untuk mengetahui pemahaman siswa terhadap materi yang sudah diajarkan.

i. Membentuk diskusi atau kelompok maksimal 5 siswa dalam setiap kelompoknya.

j. Guru memberikan evaluasi dan penjelasan terhapat materi yang belum dipahami oleh siswa.

Dalam proses pembelajaran guru memancing pengetahuan siswa dengan cara memberikan pertanyaan kepada siswa terkait materi yang diajarkan. Pada pembelajaran dalam jaringan (daring) terdapat beberapaa anak yang kurang antusias dan ada beberapa siswa yang cukup antusias belajar. Dalam diskusi bersama terlihat ada kelompok yang kurang dalam kerjasamanya anatara siswa satu dengan yang lain, karena dalam setiap kelompok ada siswa yang benar-benar antusias ingin belajar dan ada siswa yang hanya ikut dalam kelompok. biasanya siswa yang tidak serius dalam belajar mengalami kendala pada saat penumpukan tugas, terdapat beberapa tugas yang masih belum dikerjakan di buku tugas. Sebaliknya dengan siswa yang antusias dan memperhatikkan dalam pembelajaran daring.

\section{Analisis Evaluasi}

Evaluasi adalah suatu usaha yang dilakukan untuk menentukan tingkat keberhasilan peserta didik dalam pencapaian kompetensi. Pada umumnya teknik dan instrumen pengukuran diklasifikasi menjadi tes dan non-tes yang masing-masing dapat dirinci lagi menjadi beberapa macam. Tes dapat diartikan sebagai teknik atau instrumen pengakuan yang menggunakan serangkaian pertanyaan yang harus di jawab, atau tugas yang harus dilakukan secara sengaja dalam suatu kondisi yang dirancang secara khusus untuk mengetahui potensi, kemampuan dan keterampilan peserta didik sehingga menghasilkan data atau sekor yang dapat diinterprestasikan. Proses evaluasi yang harus mengandalkan teknik dan instrumen tes sangat tidak memadai. Untuk dimungkinkannya pengukuran dan penilaian yang komprehensif teknik dan instrumen berbentuk non tes dapat berperan secara efektif, terutama untuk pengukuran ranah afektif dan psikomotorik, walaupun didasari bahwa penggunaan teknik ini dalam evaluasi pendidikan masih sangat terbatas. Yang dimaksud 
instrumen non-tes dalam hubungan ini adalah serangkai pertanyaan, pernyataan, atau stimulus lain yang harus direspon peserta didik atau yang membutuhkan respon mereka dalam situasi ysng tidak atau kurang dibakukan. Untuk mengukur aspekaspek tingkah laku peserta didik yang tertarik degan tujuan pembelaaran dan Pendidikan (Shodiq, 2012).

Dalam evaluasi penerapan model pembelajaran dalam jaringan (daring) pada pembelajaran tematik guru menggunakan evaluasi lisan, tertulis, tugas individu dan kelompok. Pada pencapaian evaluasi hanya menggunakan ranah kognitif dimana siswa mengerjakan soal tugas. Sebagaimana hasil dari observasi yang dilakukan oleh peneliti menunjukan hasil yang baik karena pada saat pelaksanaan pembelajaran sudah sesuai dengan langkah-langkah yang ada.

Evaluasi digunakan untuk mengukur kemampuan belajar siswa dalam bidang kognitif. Dalam kegiatan implementasi model pembelajaran daring pada pembelajaran tematik di kelas IV SDN Gubeng 1 / 204 Surabaya, evaluasi memiliki peran yang sangat penting. Dengan menggunakan evaluasi, guru dapat mengetahui sejauh mana siswa dalam menguasai materi pembelajaran yang sudah diajarkan sekaligus dapat menjadi umpan balik bagi guru sendiri guna melakukan perbaikan dalam proses pembelajaran selanjutnya. Dalam kegiatan model pembelajaran dalam jaringan (daring) pada pembelajaran tematik kelas IV, evaluasi sangat diperlukan untuk mengetahui apakah pembelajaran yang sudah diajarkan oleh guru sudah mencapai tujuan atau belum. Dalam kegiatan evaluasi guru melakukan Tanya jawab kepada siswa tentang materi pembelajaran yang diajarkan melalui lisan maupun tulisan. Dengan memberikan pertanyaan untuk mengukur sejauh mana pemahaman siswa tentang pembelajaran.

\section{Kesimpulan}

Pembelajaran daring pertama kali diperkenalkan oleh Universitas Illionis di Urbana Champagn dengan menggunakan sistem instruksi berbasis computer. Istilah daring merupakan akronim dari "dalam jaringan". Pembelajaran daring adalah suatu sistem pembelajaran yang dapat digunakan sebagai sarana untuk proses belajar mengajar yang dilaksanakan tanpa harus bertatap muka secara langsung antara guru dengan siswa. Pembelajaran daring bertujuan memberikan layanan pembelajaran yang bermutu dalam jaringan (daring) yang bersifat masif dan terbuka untuk menjangkau peminat yang lebih banyak dan lebih luas. Daring merupakan salah satu model pembelajaran online yang dilakukan melalui jaringan internet.

Berdasarkan hasil penelitian yang dilakukan peneliti tentang implementasi model pembelajaran dalam jaringan (daring) pada pembelajaran tematik di masa pandemi covid-19 di kelas IV SDN Gubeng 1 / 204 Surabaya dapat disimpulkan sebagai berikut: implementasi model pembelajaran dalam jaringan (daring) terdapat tiga tahap yaitu tahap perencanaan pembelajaran dengan membuat silabus, rencana pelaksanaan pembelajaran (RPP), media pembelajaran dan materi pembelajaran yang akan disampaikan. Kemudian tahap dua, yaitu tahap pelaksanaan pembelajaran merupakan 
kegiatan inti dalam pembelajaran daring dalam pelaksanaan pembelajaran ada yang individu dan berkelompok. Dalam pembelajaran individu atau mandiri, siswa belajar dan mengerjakan tugas dengan sendiri. Jika berkelompok guru akan membagi maksimal lima siswa untuk berkelompok di rumah salah satu kelompoknya untuk berdiskusi dan mengerjakan tugas bersama-sama. Tahap tiga, yaitu evaluasi pembelajaran yang dilakukan oleh guru, pada tahap evaluasi guru masih mengutamakan penilaian hasil pengetahuan siswa melalui mengerjakan soal di buku siswa dan PR sebagai tugas. Implementasi model pembelajaran dalam jaringan (daring) pada pembelajaran tematik di masa pandemi covid-19 kelas IV SDN Gubeng 1 / 204 Surabaya sudah cukup berjalan sesuai dengan langkah-langkah pembelajaran walaupun pada pembelajaran masih terdapat hambatan baik dari guru maupun siswa pada saat pembelajaran berlangsung.

Pada pembelajaran dalam jaringan (daring), guru sudah berusaha semaksimal mungkin menggunakan model pembelajaran daring pada pembelajaran tematik kelas IV. Dalam langkah-langkah pembelajaran daring sudah berjalan cukup baik, melihat dari tahap perencanaan pembelajaran, pelaksanaan pembelajaran, dan evaluasi pembelajaran sesuai cukup dengan langkah-langkah.

\section{BIBLIOGRAFI}

Ahmadi, Ruslam. (2016). Yogyakarta: Ar-Ruzz Media.

Depdiknas. (2003). Undang-undang Sistem Pendidikan. Jakarta: Eka Jaya.

Dewi, Wahyu Aji Fatma. (2020). Dampak Covid-19 terhadap implementasi pembelajaran daring di Sekolah Dasar. Edukatif: Jurnal Ilmu Pendidikan, 2(1), 5561.

Dini, JPAU. (2021). Problematika pembelajaran daring dan luring anak usia dini bagi guru dan orang tua di masa pandemi Covid 19. Jurnal Obsesi: Jurnal Pendidikan Anak Usia Dini, 5(2), 1825-1836. Google Scholar

Eka, Purwandani Mulyanti. (2021). Implementasi Model Pembelajaran Dalam Jaringan (Daring) Pada Kegiatan Pemblajaran Tematik Dimasa Pandemi Covid-19 Kelas Iv Sd Negeri 01 Jatisaba Kecamatan Cilongok Kabupaten Banyumas. Iain Purwokerto. Google Scholar

Emzir. (2008). Metode Penelitian Pendidikan Kuantitatif \& Kualitatif. Jakarta: RajaGrafindo Persada. Google Scholar

Erwin Widiosworo. (2015). 19 Kiat Sukses Motivasi Belajar Peserta Didik. Yogyakarta: Ar-Ruzz Media. Google Scholar

Handayani, Diah, Hadi, Dwi Rendra, Isbaniah, Fathiyah, Burhan, Erlina, \& Agustin, Heidy. (2020). Penyakit Virus Corona 2019. Jurnal Respirologi Indonesia, 40(2), 
119-129. Google Scholar

Hasbullah. (2012). Dasar-Dasar Ilmu Pendidikan (Edisi Revisi). Jakarta: Raja Grafindo Persada.

Hasil Wawancara dengan Guru Kelas IV Ibu Erin Mega Susilowati SDN Gubeng 1 / 204 Surabaya. (2020). Hasil Wawancara dengan Guru Kelas IV Ibu Erin Mega Susilowati SDN Gubeng $1 / 204$ Surabaya, tanggal 2 September 2020, pukul 10.00 WIB.

Nawafil, Moh. (2018). Cornerstone of education:(landasan-landasan pendidikan). Absolute Media. Google Scholar

Shodiq, Abdullah. (2012). Evaluasi Pembelajaran Konsep Dasar, Teori dan Aplikasi. Semarang: Pustaka Rizki Putra. Google Scholar

Sofan Amri. (2013). Pengembangan \& Model Pembelajaran dalam Kurikulum 2013. Jakarta: Prestasi Putrakarya.

Sugiyono. (2010). Metode Penelitian Pendidikan. Bandung: Alfabeta. Google Scholar

Trianto. (2010). Pengembangan Model Pembelajaran tematik. Jakarta: Prestasi Pustakakarya.

UU No.20 tahun 2013. (2013). Sistem Pendidikan Nasional. Google Scholar

Wahyuni, Fitri. (2015). Kurikulum dari masa ke masa. Jurnal, Al-Adabiya, 10(2).

Wawancara bersama guru kelas IV SDN Gubeng 1 / 204 SurabayaErin Mega Susilowati. (2020). Wawancara bersama guru kelas IV SDN Gubeng 1 / 204 SurabayaErin Mega Susilowati.

Zidane, Jelang. (2021). Penggunaan Media Pembelajaran Google Classroom Pada Pembelajaran Daring Kelas V Sd Negeri 1 Punung Tahun Ajaran 2020/2021. Stkip Pgri Pacitan. Google Scholar

\section{Copyright holder:}

Sri Juniati (2021)

First publication right:

Syntax Idea

This article is licensed under:

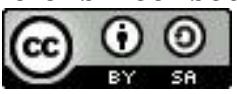

